\title{
Revolusidalam Perkembangan Astronomi: Hilangnya Pluto Dalam Keanggotaan Planet Pada Sistem Tata Surya
}

\author{
Oka Saputra \\ Program Studi pendidikan IPA Universitas Pendidikan Indonesia \\ e-mail: okasaputra@upi.edu
}

\begin{abstract}
Astronomi merupakan ilmu yang mempelajari tentang benda langit, seiring dengan berkembangnya teknologi maka terjadi pergeseran paradigma.Pergeseran paradigma (paradigm shift) adalah istilah yang cocok untuk menggambarkan terjadinya dimensi kreatif pikiran manusia dalam bingkai pengetahuan.Salah satu perubahan paradigma adalah keanggotaan Pluto dalam planet pada tata surya.Tahun 2006 hal yang sangat mengejutkan dimana IAU (International Astronomical Union) mengatakan bahwa Pluto yang kita kenal sebagai planet terjauh yang mengeliligi alam semesta bukanlah sebuah planet dan di hilangkan dalam keanggotaan planet dan Pluto di golongkan kedalam planet kerdil.
\end{abstract}

Kata Kunci: Astronomi, benda langit

\section{Pendahuluan}

Sejarah memperlihatkan bahwa sains berkembang secara pesat sejak kelahirannya pada abad-abad pertengahan hingga saat ini. Pengetahuan ilmiah tumbuh bagai deret ukur, kecepatan pertumbuhannya semakin lama semakin tinggi. Dalam perkembangan ilmu secara kasat mata nampak penggantian gagasan-gagasan ilmiah lama oleh yang baru sesuai dengan fakta-fakta baru yang ditemukan, sehingga terbedakan gagasan modern dari gagasan klasik (Firman, 2016).

Alam semesta merupakan bagian yang tidak terlepas dari dunia sains, dan astronomi merupakan cabang ilmu sains yang membahas hal tersebut.Perspektif pemikiran sains di bidang astronomi sampai saat ini masih menjadi perdebatan paradigma yang tidak kunjung usai(Thoha $d k k, 2017)$.

Kuhn (1962) mendefenisikan bahwa paradigma merupakan istilah yang digunakan untuk mendeskripsikan sekumpulan ide, asumsi, dan metode yang dibagikan oleh sekelompok ilmuwan; ketika ini rusak, itu mengarah ke pergeseran paradigma ke model teoritis baru.

Pergeseran paradigma (paradigm shift) adalah istilah yang cocok untuk menggambarkan terjadinya dimensi kreatif pikiran manusia dalam bingkai pengetahuan. Pergeseran paradigma merupakan letupan ide yang merangsang timbulnya letupan ide-ide lain, terjadi terus-menerus, sambung menyambung, baik pada orang yang sama maupun orang yang berbeda. Reaksi berantai ini pada akhirnya menjadi kekuatan yang bisa merubah wajah dan tatanan dunia serta peradaban manusia ke arah suatu kemajuan ilmu pengetahuan (Hamdani, 2011).

Salah satu pergeseran paradigma dalam bidang astronomi adalah tidak dianggapnya pluto sebagai planet ke Sembilan atau dengan kata lain pluto bukan merupakan anggota dari planet yang mengelilingi matahari. Mengenai perdebatan planet ke Sembilan ternyata masih banyak peneliti yang menyelidiki tentang adanya planet ke Sembilan (Holman \& Payne, 2016).

Perdebatan paradigma tentang apakah pluto merupakan planet atau bukan menjadikan kita harus meninjau ulang dasar keilmuan yang di dapat dari tingkat sekolah yang mengatakan Pluto adalah planet. Tinjauan ini perlu di dasarkan oleh bukti empiris yang bersesuaian dengan teori dan hasil yang relevan. 


\section{Metode}

Penelitian ini termasuk jenis penelitian studi literatur dengan mencari referensi teori yang relefan dengan kasus yang diangkat dalam artikel ini yaitu revolusidalam perkembangan astronomi: hilangnya pluto dalam keanggotaan planet pada sistem tata surya.

\section{Hasil dan Pembahasan}

Tata Surya merupakan sebuah sebuah sistem yang terdiri dari Matahari, delapan planet, planet-kerdil, komet, asteroid dan benda-benda angkasa kecil lainnya. Matahari merupakan pusat dari Tata Surya di mana anggota Tata Surya yang lainberedar mengelilingi Matahari.Benda-benda langit tersebut beredar mengelilingi Matahari secara konsentris pada lintasannya masing-masing.

IAU secara umum mengelompokkan benda angkasa yang mengeliligi Matahari menjadi tiga yaitu: (1) Planet; (2) Planet-Kerdil; (3) Benda-benda Tata Surya Kecil (Small Solar System Bodies) yaitu seluruh benda angkasa lain yang mengelilingi Matahari selain planet atau planetkerdil. Benda-benda Tata Surya Kecil tersebut di antaranya adalah komet, asteroid, objek-objek trans-neptunian, serta benda-benda kecil lainnya.

\section{Anggota Tata Surya Matahari}

Matahari merupakan sebuah bintang yang jaraknya paling dekat ke Bumi.Jarak rata-rata Bumi ke Matahari adalah 150 juta $\mathrm{Km}$ atau 1 Satuan Astronomi.Matahari berbentuk bola gas pijar yang tersusu atas gas Hidrohen dan gas Helium.Matahari mempunyai diameter $1,4 \times 10^{6}$ $\mathrm{Km}$, suhu permukaannya mencapai $6000^{\circ} \mathrm{K}$. Matahari merupakan sumber energi utama bagi planet Bumi yangmenyebabkan berbagai proses fisis dan biologi dapat berlangsung.Energi yang dipancarkan oleh Matahari dibentuk di bagian dalam mataharimelalaui reaksi inti.Energi dipancarkan oleh Matahari ke Bumi dalam bentukadiasi gelombang elektromagnetik.

\section{Komet}

Komet juga disebut dengan bintang berekor adalah benda langit yang garis edar/otbitnya sangat lonjong, sehingga jaraknya ke matahari kadang-kadang jauh sekali tetapi suatu saat dapat dekat sekali.Ekor komet selalu menjauhi matahari sebab mendapatkan tekanan dari matahari.Wujud komet tersusun dari kristal-kristal es yang rapuh sehingga mudah terlepas dari badannya.Bagian yang terlepas inilah yang membentuk semburan cahaya ketika sebuah komet melintas di dekat Matahari. Karena orbit komit tidak seperti orbit planet maka komet akan terlihat di bumi jika komet tersebut sedang berada dekat dengan Matahari. Oleh karena itu ada komet yang mendekati Bumi setiap 3 atau 4 tahun sekali; tetapi ada juga yang sampai 76 tahun sekali yaitu Komet Halley.

\section{Meteor dan Meteorit}

Meteor adalah benda angkasa berupa pecahan batuan angkasa yang jatuh dan masuk ke dalam atmosfer bumi. Ketika meteor masuk ke dalam atmosfer bumi maka akan terjadi gesekan dengan udara sehingga benda tersebut akan menjadi panas dan terbakar. Meteor yang tidak habis terbakar di atmosfer bumi dan sampai ke permukaan bumi disebut meteorit.Tumbukan meteorit berukuran besar pada permukaan bumi seringkali menimbulkan lubang besar di permukaan bumi yang disebut kawah meteorit, contohnya Kawah Meteorit Arizona di Amerika Serikat yang lebarnya sekitar $1.265 \mathrm{~m}$.

\section{Astroid}

Asteroid dinamakan juga planet minor atau planetoid.Asteroid mengisiruangan yang berada diantara Mars dan Yupiter.Di dalam sistem Tata Surya ditaksir terdapat 100.000 buah planetoid yang ukurannya antara $2-750 \mathrm{Km}^{2}$. Asteroid-asteroid tersebut senantiasa berputar diantara planet Mars dan planet Jupiter membentuk sabuk asteroid.

Satelit

Satelit adalah benda langit pengiring planet.Satelit senantiasa mengiringidan berputar terhadap planet pusatnya.Berdasarkan cara terbentuknya satelit dapat dibedakan menjadi 2 bagian, yaitu : (a) Satelit Alam, adalah satelit yang terbentuk karena adanya peristiwa alam bersamaan dengan terbentuknya planet. Contoh: Bulan, sebagai satelit alam Bumi; Titan, sebagai satelit alam Saturnus, (b) Satelit Buatan, adalah satelit yang dibuat oleh manusia yang digunakan untuk tujuan tertentu. Contoh: Satelit cuaca, satelit komunikasi, satelit mata-mata, dan sebagainya. 
Pada umumnya planet-planet dalam sistem tata surya mempunyai beberapasatelit yang senantiasa mengiringinya. Hanya planet Merkurius dan planet Venusyang tidak memiliki satelit.

\section{Planet}

Planet adalah suatu benda gelap yang mengorbit sebuah bintang (matahari).Planet ditentukan oleh para ahli astronomi melalui serangkaian pengamatan dan penelitian selama ribuan tahun.Planet yang telah ditemukan oleh para ahli secara berturut-turut adalah Merkurius, Venus, Bumi, Mars, Jupiter, Saturnus, Uranus, Neptunus, dan Pluto.Penemuan lebih muktahir menyebutkan bahwa planet yang telah ditemukan hingga sekarang lebih dari jumlah tersebut.Masing-masing planet memiliki jarak terhadap matahari yang berbeda. Selain itu, masing-masing planet memiliki bentuk, kerapatan, kala revolusi, dan kala rotasi yang berbeda satu sama lain (Rohmah, 2012).Berdasarkan kriteria IAU, planet adalah benda langit yang: mengorbit Matahari, bentuk fisiknyanya cenderung bulat, orbitnya bersih dari keberadaan benda angkasa lain

\section{Revolusi IImiah Status Pluto}

Salah satu dampak utama dari revolusi sains adalah perubahan pandangan dunia (world view) yang menaungi para ilmuwan dalam seluruh aktivitas ilmiah mereka. Hasilnya adalah perubahan paradigma yang menyebabkan para ilmuwan melihat dunia mereka secara berbeda. Paradigma baru ini selanjutnya akan menjadi fase sains normal sampai terjadinya keadaan anomali dan krisis paradigma berikutnya yang akan melahirkan paradigma baru, dan seterusnya. Jadi, menurut Kuhn ilmu berkembang melalui siklus-siklus, sains normal diikuti oleh revolusi, yang diikuti lagi oleh sains normal, dan kemudian diikuti lagi oleh revolusl (Sutarno $d k k$ 2017).

Proses revolusi sains menuju sains normal bukanlah jalan bebas hambatan. Sebagian ilmuwan atau masyarakat sains tertentu ada kalanya tidak mau menerima paradigma baru. Hal ini menimbulkan masalah sendiri yang memerlukan pemilihan dan legitimasi paradigma yang lebih definitif. Para ilmuwan yang tidak mau menerima paradigma baru sebagai landasan risetnya akan tetap bertahan pada paradigma yang telah dibongkar dan sudah tidak mendapat dukungan dari mayoritas masyarakat sains, maka aktivitas-aktivitas risetnya hanya merupakan tautologi yang tidak bermakna (Zubaedi, 2007).

Salah satu revolusi sains yang menghebohkan adalah Pluto tidak dikategorikan lagi sebagai planet.Ada perbedaan pendapat mengenai pengelompokan Pluto sebagai planet.Pluto dikelompokkan sebagai planet kesembilan segera setelah penemuannya dan pengelompokkan ini sudah berjalan selama 75 tahun.Pluto dalam bahasa Yunani berarti Hades, yaitu nama dewa dunia penjahat Yunani. Setelah mendapat banyak usulan pemberian nama planet kesembilan dari sistem tata surya ini, dipilihlah nama Pluto. Pemberian nama "Pluto" mungkin dikarenakan letaknya yang sangat jauh dari matahari dan selalu dalam kegelapan. Ada juga dugaan huruf PL pada nama Pluto merupakan singkatan dari Percival Lowell. Percival Lowell adalah pendiri Observatorium Lowell di Arizona Amerika.Ahli-ahli astronomi di Observatorium Lowell melakukan penelitian untuk mencari planet kesembilan.Setelah melalui serangkaian penelitian yang panjang, akhirnya Clyde W. Tombaugh seorang ahli astronomi yang bekerja di Observatorium Lowell berhasil menemukan planet yang mereka cari pada tanggal 18 Februari 1930. Pengamatan lanjutan dilakukan dan pada tangal 13 Maret 1930 Observatorium Lowell secara resmi mengumumkan penemuan Pluto.

Ahli astronomi membuat hipotesis adanya kelompok besar dari benda beku yang berada dalam Sabuk Kuiper.Sabuk Kuiper terdapat pada pinggiran sistem tata surya kita.Benda dalam Sabuk Kuiper pertama ditemukan pada awal tahun 1990.Para ilmuwan mengakui bahwa Pluto yang ditemukan tahun 1930, sebenarnya hanyalah satu dari beberapa benda dalam Sabuk Kuiper. Dalam hal susunan dan orbitnya, Pluto berbeda dengan delapan planet yang lain, tetapi mempunyai kemiripan dengan benda-benda yang ada di Sabuk Kuiper.Sampai tahun 2003, Pluto masih merupakan benda terbesar dalam Sabuk Kuiper hingga ditemukan 2003 UB313.Timbullah pertanyaan tentang status Pluto sebagai planet seutuhnya.

Perbedaan pendapat mengenai status Pluto sebagai planet terjadi selama beberapa tahun. Sehingga pada tanggal 24 Agustus 2006, IAU (International Astronomical Union) Perserikatan Astronomi Internasional memutuskan pengertian baru tentang planet dan tidak memasukkan Pluto sebagai planet.Berdasarkan kriteria IAU, planet adalah benda langit yang: (1) mengorbit Matahari; (2) bentuk fisiknyanya cenderung bulat; (3) orbitnya bersih dari keberadaan benda angkasa lain. Pluto tidak dikategorikan lagi sebagai planet karena kriteria ke tiga dari tiga kriteria di atas tidak dipenuhi oleh Pluto. Pluto memiliki orbit yang memotong orbit 
Neptunus sehingga dianggap orbit Pluto belum bersih dari benda angkasa lain. Ukuran Pluto tidak lebih besar dari Bulan dan jika dilihat dengan teleskop maka akan tampak benda angkasa lain yang ukurannya hamper sama dengan Pluto yaitu yang diberi nama Charon.

Menurut pengertian IAU, sistem tata surya kita memiliki delapan planet, yaitu Merkurius, Venus, Bumi, Mars, Jupiter, saturnus, Uranus, dan Neptunus. Pluto dikelompokkan sebagai planet kecil, dan planet kecil tidak sama dengan planet yang sesungguhnya. Untuk saat ini, kita hanya mengenal tiga kelas untuk benda-benda di Tata Surya, yakni planet, planet kerdil, dan benda-benda kecil lainnya. Planet Tata Surya yang sekarang terdiri dari delapan planet dan tidak memasukkan Pluto. Pluto termasuk planet kerdil, sama dengan 2003 UB313, asteroid Ceres, Quoaoar, dan Sedna. Benda kecil lainnya adalah asteroid kecil, komet, dan meteoroid.

\section{Kesimpulan}

Astronomi adalah cabang ilmu alam yang meneliti benda langit (seperti bintang, planet, komet) serta fenomena-fenomena alam yang terjadi di luar atmosfer Bumi (misalnya radiasi latar belakang kosmik). Salah satu kajian dari astronomi adalah Pluto.Pluto ditemukan pada tahun 1930, oleh seorang astronom yang mengira bahwa ia telah berhasil menemukan planet ke sembilan di tata surya, untuk sebuah planet di tata surya kita, ukurannya memang terbilang kecil. Tetapi para astronom pada saat itu, sangat yakin bahwa Pluto memang planet ke sembilan di tata surya kita.Kemudian permasalahannya muncul, ketika teleskop yang lebih canggih berhasil dikembangkan pada saat itu. Dari hasil pengamatan, kita mengetahui bahwa Pluto, hanyalah salah satu dari banyak sekali objek langit yang berada di area yang bernama Banyaknya objek langit seperti Pluto di luar sana, membuat para astronom akhirnya membuat syarat untuk sebuah objek langit, bisa disebut sebagai planet dan plutu tidak memenuhi salah satu kriteria untuk dikatakan planet. Tetapi kemudian, untuk mengelompokkan planet-planet seperti Pluto ini, para astronom menciptakan sebutan khusus yang bernama "dwarf planet" atau planet kerdil.

\section{Daftar Pustaka}

Firman Harry. (2016). Perkembangan IImu. Bahan ajar Filsafat ilmu Program Doktoral UPI. Tidak diterbitkan.

Hamdani.(2011). Filsafat Sains. Bandung: CV Pustaka Setia.

Ikhlasul. (2016). Pluto, Planet? PGSD FIP Universitas Negeri Yogyakarta.Tidak diterbitkan.

Kuhn, T.S. (1989). Peran Paradigma Dalam Revolusi Sains. Bandung : Remaja Rosdakarya.Firman Harry. (2016). Perkembangan Ilmu. Bahan ajar Filsafat ilmu Program Doktoral UPI. Tidak diterbitkan.

Ono, Y. W. (2012). Modul Tata Surya. Unioversitas Negeri Yogyakarya. Tidak diterbitkan.

Rohmah, U. (2012).Aplikasi Augmented Reality Tata Surya (Semua Planet Mengelilingi Matahari) Menggunakan Mobile Android. Jakarta: Fakultas IImu Komputer dan Teknologi Informasi Universitas Gunadarma

Sutarno, Erwin \& Hayat, M. S. (2017). Radiasi Benda Hitam dan Efek Fotolistrik Sebagai Konsep Kunci Revolusi Saintifik dalam Perkembangan Teori Kuantum cahaya.Titian IImu: Jurnal IImiah Multi Sciences Vol. IX No. $251-58$

Thoha \& Sinensis, A. R. (2017). Perdebatan Paradigm Teori Revolusi: Matahari Atau Bumi Sebagai Pusat Tata Surya?.Titian IImu: Jurnal Ilmiah Multi Sciences Vol. IX No. 123 32

Zubaedi.(2007). Filsafat Barat: dari Logika Baru Rene Descartes hingga Revolusi Sains ala Thomas Kuhn. Yogyakarta: Ar-Ruzz Medi. 